\title{
Moderating role of Boards' Equity ownership on the relationship between Corporate Governance and the Performance of Bailed-out Banks in Nigeria
}

\author{
Nuraddeen S. Aliyu ${ }^{1,2}$, Che Zuriana Muhammad Jamil ${ }^{1}$ and Rapiah Mohamed ${ }^{1}$ \\ ${ }^{1}$ School of Accounting, College of Business, Universiti Utara Malaysia \\ ${ }^{2}$ Department of Accounting, Ahmadu Bello University Zaria, Nigeria
}

\begin{abstract}
This paper proposes the moderating role of board equity ownership in the relationship between corporate governance and performance of banks in an era of post banking crisis that called for a bailout reform. The board attributes were selected based on the peculiar problem of the banking sector, and based on the board functions that captures monitoring (agency theory based).
\end{abstract}

Keywords: Corporate governance, Board equity ownership, Banks performance

\section{Introduction}

Banking system as a subset of financial system plays a vital role in the economic growth and development of an economy. As financial intermediaries, banks assist in channelling funds from surplus economic units to deficit areas to facilitate business transactions and economic development generally. Since these funds are owned by third parties, prudence demands that such funds should be efficiently managed to sustain the confidence of depositors in the banking system, enhance efficiency, ensure the continued soundness of the system itself and thereby minimize the risk of bank failures (Oluranti, 1991). In the Nigerian financial sector, poor managerial performance and poor corporate governance $(\mathrm{CG})$ had been identified as the major factors in virtually all known cases of a financial institution's distress in the country which even led to consolidation reform in 2004, and yet re-emerged afterwards, and led to another reform in late 2009 that necessitated the bail-out of ten (10) banks which nearly collapsed due to high non-performing loans, poor CG, bad liquidity and risk management (CBN, 2010). The bail-out reform became the only rescue program which could ensure the continuous survival of the banking industry by injecting N620 billion. This bail-out reform generated a lot of panic and doubt concerning the status of the investments of these banks' depositors, shareholders and other Nigerians consequently, led to a sparked interest in examining the potential outcome of this reform through researches.

However, this paper aims at proposing a framework that could examine the potential relevance of board equity ownership (BEO) in influencing the relationship between CG and the performance of these bail-out banks. This study is hence is proposing a framework that selects the most appropriate board variables that best address the banks' CG problems peculiar to Nigeria, and introducing a moderating variable (BEO) that will strengthen the inconsistent conflicting relationship between CG and banks performance indirectly, as suggested Hillman \& Dalziel, (2003) and Zahra \& Pearce, (1989). This framework, unique as it is, aims at covering only the bailed-out banks with a total of 2,811 branches in Nigeria using a primary source of data (questionnaire). There is paucity of studies that use BEO as moderating variable that captures board control or monitoring role which addresses the Nigerian bail-out banks, hence the need to be introduced into these inconclusive findings.

Due to the financial crisis that hit the globe, the mid 2000s saw a renewed academic interest in the field of CG and firm performance. However, most researches conducted globally and Nigeria in particular, are having some kind of shortcomings which results in usual conflicting findings like: inconsistent operationalization of board variables, limited scope, and convenience samples, and usual focus mainly on the direct relationships between board variables and firm's performance, thus ignoring the indirect path (through roles and strategic initiatives (Hillman \& Dalziel, 2003; Zahra \& Pearce, 1989). Studies in the Nigerian context which adopts a moderating variable that captures board control or monitoring role are very rare, hence the need to be introduced into these inconclusive relations/findings. Also, most of the studies on CG in Nigerian context are either conducted before the banks' bail-out, or not in the area of bail-out reform or not covering the banking sector such as Adekoya, (2011); Okereke, Abu, \& Anyanwu, (2011); Onakoya, Ofoegbu, \& Fasanya, (2012); Uwuigbe \& Fakile, (2012). Only few studies were found on bail-out such as "Kuye, Ogundele, \& Otike-Obaro, (2013); Nworji, (2011); Oghojafor, Olayemi, Okonjia, \& Okolie, (2010)", which all have certain kind of shortcomings, small sample, addressing policy issue not the banks' performance etc. Studies on CG covering both financial and non-financial performance are very rare in Nigeria except Ogbechie et al. (2009). The outcome of this paper shall be of immense importance to academics, regulators, shareholders, and other Nigerians as it will reveal the 
Moderating role of Boards' Equity ownership on the relationship between Corporate Governance ..

contribution of BEO in strengthening board of directors' functions in ensuring good banks' performance. The paper is subdivided into 5 sections from introduction, literature review, BEO (moderator), Bank performance, framework, conclusion then reference.

\section{Literature Review}

\subsection{Nigerian Banking Crisis/Reforms}

Historically, the banking system in Nigeria after commencement in 1892, has experienced so many major challenges and several episodes of the banking crisis. Several major reforms were introduced by the Federal Government of Nigeria (FGN) through the Central Bank of Nigeria (CBN), to sought permanent measures that would enhance the stability and efficiency of the banking sector. For example, reforms like Structural Adjustment Program (SAP) in 1986, financial liberalization in 1987/88 (such as the decontrolling of interest rates), then 1991, prudential guidelines was brought to classify loaned asset quality and prevent bank distress and lastly consolidation reform in 2004 was implemented. All these had an objective of eliminating banks' failure/distress. To strengthen banks' liquidity position, CBN increased minimum capital base required for commercial banks operating in Nigeria four times between year 1990 and 2004, for instance, in 1992 (from N20 million to N50 million), 1998 (from N50 million to N500 million), 2002 (from N500 million to N2 billion) and 2004 (from N2 billion to N25 billion) respectively (Iganiga, 2010). However, these measures were unsuccessful in curtailing the spate of bank distress and failures in the 1990s and beyond (Aburime, 2008; Beck, Cull, \& Jerome, 2005; Iganiga, 2010; Oluranti, 1991).

Recently, due to a major hit by the global financial crisis, another set of banking sector rescue program "Bail-out" was inevitably being introduced to ensure stability and prevent distress. The Central Bank of Nigeria (CBN) and the Nigeria Deposit Insurance Corporation (NDIC) in July 2009, conducted a joint special examination of all 24 deposit banks in Nigeria, with the purpose of evaluating their health, with especial focus on Liquidity, Capital adequacy, Risk management and Corporate Governance practices (CG). The governor of CBN Mal. Sanusi Lamido Sanusi, declared ten (10) banks of the Nigerian banking sector as being distressed due to "excessively high level of non-performing loans in the banks, which was attributable to poor corporate governance practices, bad liquidity position and risk management". Consequently, a bail-out of about N620 billion was injected to rescue them, and then the Managing Directors (MD/CEOs) and the board of directors of 8 banks were immediately removed and then replaced with new ones. These CEOs were then detained, prosecuted by the economic and financial crimes commission (EFCC) and also tried before the high court for outright stealing, corruption and mismanagement of their banks (NDIC, 2011; CBN, 2010; Sanusi, 2010). The CBN has also appointed advisory companies like Deutsche Bank, Chapel Hill Denham, KPMG Professional Services and Akintola Williams Deloitte etc. to work with the new boards and management of these banks by exploring all options for securing their stability and long-term future growth. They are also expected to explore all possibilities for institutionalising best practice and good corporate governance at each of the banks, in furtherance of the CBN's desire that the interests of all stakeholders are respected. This Press release by the Governor of the apex regulatory body of Nigeria's money market, thus, reiterated the importance of the concept of managerial performance, corporate governance as well as corporate performance to researchers, regulators, investors and the general public.S

\subsection{Corporate Governance}

Also, this study adopts agency theory in the framework as in de Villiers, Naiker, \& van Staden, (2011); Hillman \& Dalziel, (2003) which opined that boards have the functions of monitoring management's activities. Agency theorist asserts that management initiates and implements business plans, strategies, and systems whereas directors monitor it (de Villiers et al., 2011; Zahra \& Pearce, 1989). Under this view, independent directors and directors who own shares will be more likely to monitor rigorously (Bhagat \& Bolton, 2008; de Villiers et al., 2011; Hillman \& Dalziel, 2003). This study therefore, propose two out of its four board variables and make proposition in this paper which reflect directors' monitoring role (driven by agency theory). Additionally, these variables were actually selected based on their prominent importance in solving the practical problem of corporate governance in Nigerian banks as mentioned in (Sanusi \& CBN, 2010).

\subsection{Board Monitoring function (Agency theory based)}

According to the agency theorists, firms are often characterized by a conflict of interest between firms' management and shareholders, where managers usually exploit their control over firm operations to increase their short-term wealth at the expense of shareholders' long-term interests as opined by Fama \& Jensen, (1983) and Jensen \& Meckling, (1976). However, the presence of vigilant directors can reduce such agency costs by close monitoring of firm management activities, control system (Daily et al., 2003; Hermalin \& Weisbach, 1991; Hillman \& Dalziel, 2003; Westphal, 1999). Directors who intensely monitor management, are more likely to demand explanations for management's strategic initiatives and to criticize misguided initiatives (de Villiers 
Moderating role of Boards' Equity ownership on the relationship between Corporate Governance ..

et al., 2011; McNulty \& Pettigrew, 1999).However, to the best of our knowledge, no study has been conducted using these selected variables together in a single framework on the Nigerian bail-out banks. Therefore, these board characteristics are proposed to examine their indirect effect on banks' performance with the influence of a moderator (board equity ownership) due to the inconclusive, conflicting findings about the relationship of these variables to firm performance (Baron \& Kenny, 1986). Also, since boards' ownership is found to be related to firm performance, then it can moderate $\mathrm{CG}$ to performance.

\section{Board Equity Ownership (Moderator)}

Practically, the implementation of CBN code of corporate governance in Nigeria, posed some challenges, prominent among which were: ambiguities regarding the appointment of independent directors and the share ownership status of these independent directors(CBN, 2008). Thus, it has been an unresolved debate concerning the potential importance/ effect of board members' equity ownership on both the board functional performance and firm performance. Albring et al. (2013), opined that in the USA, the Blue Ribbon Committee (1999), among others, suggests that director stock ownership should reduce agency problems and therefore the need for external monitoring. Thus, in an attempt to make a proper alignment of the interest of director and shareholders, many boards have implemented stock ownership guidelines and holding requirements for directors, leading to a substantial rise in the ownership of managers and directors but in Nigeria, there exist ambiguities and challenges regarding the directors share ownership status (CBN, 2008).

There exist conflicting researchers views regarding this which uptil now, no clear position is given by the CBN. This show the real extent of the misconception on whether or not equity ownership by the board of Directors would influence their mandated functions. Also, the percentage of the shareholding is still not clearly determined. However, Bhagat \& Bolton, (2008); de Villiers et al., (2011); Hillman \& Dalziel, (2003) opined that Stock ownership aligns the interests of the directors with those of shareholders. Bhagat \& Bolton, (2008)'s study further revealed that particularly in poor firm performance, the likelihood of disciplinary management turnover (replacement) is positively correlated with stock ownership of board members. As such, directors with more equity ownership are likely to objectively evaluate firm performance and control firm choices (Patton \& Baker, 1987). Similarly, Weisbach, (1988) also reported that CEO replacement in poorly performing firms was greater as the representation of independent outside directors increases. Board members (both executive and nonexecutive) share ownership reduces manager/shareholder conflicts. To the extent that executive board members own part of the firm, they develop shareholder-like interests and are less likely to engage in behaviour that is detrimental to firms' / shareholders interest. In support, Kren and Kerr, (1997) shows that boards with significant holdings are more likely to link CEO pay to firm performance and replace CEOs of poorly performing firms (Bhagat \& Black, 2000).

On the contrary view, Demsetz and Lehn (1985) reported no correlation between board's ownership and firm performance, and opined that there trivial support for the divergence of interests between managers and shareholders. Fama and Jensen (1983) argued that contribution of board's ownership is considered as a "twoedged knife" in which there is an optimal level of board ownership which contributes positively to a firm's performance. However, the study of Morck, Shleifer and Vishny (1988) revealed that firm performance first improves as ownership rises up to $5 \%$, then falls as ownership increases up to $25 \%$ and then rises slightly at higher ownership. McConnell and Servaes (1990) provide further evidence on the relation between the distribution of equity ownership and firm value and find a significant curvilinear relation between them. By and large, board ownership, was viewed as an encouragement that will help board members supervise management in a more efficient way. Consistent with the positive view, (Jensen \& Murphy, 1990; Chung \& Pruitt, 1996; Mehran, 1995) supported that, board's ownership will improve firm's performance and are positively correlated. More related to this study, (Bhagat \& Bolton, 2008; de Villiers et al., 2011; Hillman \& Dalziel, 2003); Westphal, 1999) show that director ownership influence or improves boards' monitoring of strategic decision making. (Hillman \& Dalziel, 2003) argue that ownership incentives motivate directors to forgo short- term returns for long-term projects and strategies.

The study further argues consistent with many studies like Albring et al., (2013), Bhagat and Bolton, (2008); de Villiers et al., (2011); Guest, (2008)that, if these banks' board of directors were having a substantial equity ownership in the banks or compensated with equity as incentives for a targeted performance, they would definitely have monitored and counselled those sacked incompetent/fraudulent banks' managements. In the current aftermath of banking crisis, it is plausible that higher ownership could motivate directors to monitor and provide resources (advices, counsel connections etc.) to management which will in-turn lead to higher firm performance in the long run. Thus, we form the following proposition:

P.1 Banks are more likely to have better performance as the share ownership of the board of directors' increases.

P.2 Share ownership of board of directors has a relationship with the banks' performance after the bail-out. 
Moderating role of Boards' Equity ownership on the relationship between Corporate Governance ..

\section{Independent variables (IV) \\ 3.2 Board independence (IV)}

In Nigeria, many banks' boards lacked independence, the bank chairman/CEO often had an overbearing influence on the board, resulting to directors failing to make sound contributions in safeguarding the growth and development of their banks. (Sanusi \& CBN, 2010). Board independence is still one of the provisions of the $\mathrm{CBN}$ code that, $\mathrm{CBN}$ on-site verification reports of some institutions revealed non-compliance with (CBN, 2008). However, prior evidence of agency theory based researches(Fama \& Jensen, 1983; Jensen \& Meckling, 1976; Lefort \& Urzúa, 2008; Zahra \& Pearce, 1989)revealed that board members are more vigilant in exercising their monitoring functions when they are independent of the firm management and when they are often offered economic incentives to do so (Byun, Lee, \& Park, 2013; de Villiers et al., 2011; Hillman \& Dalziel, 2003; Sanda, Mikailu, \& Garba, 2005).Previous researches revealed that the higher the concentration of independent directors on the board, the higher will be the level of effective monitoring by the board(Albring et al., 2013; Hermalin \& Weisbach, 1991). This is because CEOs have less power over independent directors, as their careers are not dependent on the CEO, thus no any obligation between them.

Also, independent directors and other directors who own shares will be more likely to monitor rigorously (de Villiers et al., 2011; Hillman \& Dalziel, 2003). Since the studies of (Hillman \& Dalziel, 2003; Dalton et al., 2003; Boyd, 1994) reveals that compensating boards with equity and their level of equity ownership moderates the relationship between the board's ability to monitor/ provide resources and their actual monitoring/resources provision. Weisbach, (1988) also reported that CEO replacement in poorly performing firms was greater as the representation of independent outside directors increases. Consistent with these findings and the above- mentioned arguments on board independence, and board equity ownership, this study argues that board equity ownership could influence the independent directors' functional ability to monitor or provide resources to management which will in-turn enhance the banks' performance. Also, further argues that a board with a higher concentration of independent directors is more likely to objectively direct knowledge and expertise toward monitoring banks' performance after the bail-out. Thus, we form the following proposition:

P.3 Board members independence is positively related to Banks performance after the bail-out.

P.4Board equity ownership moderates the relationship between Independent board members monitoring functions and banks' performance after the bail-out.

\subsection{Audit committee quality (IV)}

This is indeed a very sensitive board attribute that provides monitoring control roles of boards. Albring et al. (2013) reported that the best measure of audit committee quality is accounting financial expertise, because the perceived lack of accounting and financial expertise by boards and audit committees triggered a widespread regulatory and public attention (Hilzenrath, 2002). A competent and effective audit committee could improve the credibility and reliability of the financial statements provided to users (Abernathy, Herrmann, Kang, \& Krishnan, 2013). Frequent evaluations of CEO and firm performance by the board or a standing committee will result in feedback for appropriate corrective actions (Zahra \& Pearce, 1989). They also, opined that the structure of a board also plays a vital role in determining directors' success in executing their control roles. This is because, an audit committee that has competent directors and well run, and also, the directors' accessibility to timely and reliable control data is highly inevitable in evaluating both management and firm performance and also enables them to monitor progress in achieving company goals especially through performance measurement (Zahra \& Pearce, 1989). In this study, we proxy the audit committee quality as to the presence of a competent (professional accountant or financial expertise, i.e. practicing auditor /financial analysts). However, recent researches tend to focus on the competence of audit committee as against their previous focus on independence. This is because only board members who are financially educated (accountants or auditors), can be able to diagnose the true\& fairness of the firm's financial report even before publishing and monitors the frequent performance measurement of CEO, top management staff and the business units of the firm in order to ensure survival of these banks after the bail-out reform.

However, previous research suggests that audit committees with financial experts as members are more effective at monitoring the process and quality of financial reporting especially in ; the effects of materiality justification and accounting precision (DeZoort, Hermanson, \& Houston, 2003); detecting material misstatements (Abbott, Parker, \& Peters, 2004; Raghunandan, Read, \& Rama, 2001), curtailing of internal control problems (Krishnan, 2005; Zhang et al., 2007) and restatements (Agrawal \& Chadha,2005), and increasing the responsiveness to events indicative of failure in the financial reporting process (Chen \& Zhou, 2007;Krishnamurthy, Zhou, \& Zhou, 2006; Zhang, Zhou, \& Zhou, 2007;).(Abbott et al., 2004) reported that an audit committee's supervisory role could be discounted by the external auditor if he observes that the audit committee does not have the necessary knowledge/experience to understand technical auditing and financial reporting matters (Cohen et al. 2002). Furthermore, a knowledgeable audit committees are better equipped to understand auditor judgments and discern the substance of disagreements between management and the external 
auditor (Abbott et al., 2004; DeZoort and Salterio, 2001).In support of prior studies (Albring et al., 2013; Carol Liu, Tiras, \& Zhuang, 2014; de Villiers et al., 2011; Hillman \& Dalziel, 2003)we predict that the independent directors who owns equity shares in the banks, and are members of audit committee with financial/audit expertise, are more likely to be effective in monitoring the quality of periodic financial reports presented by management and bank's performance. Thus the following proposition is formed:

P5. Audit committee quality is positively related to Banks performance after the bail-out.

P6. Board equity ownership moderates the relationship between qualitative audit committee monitoring functions and banks' performance after the bail-out.

\section{Banks Performance}

Organisational performance is an important concept that relates to the way and manner in which financial, material and human resources available to an organization are judiciously used to achieve the overall corporate objective of an organisation. Various measurement models were previously developed to take care of either managerial or organisational or both performance. However, among them all this study adopts the Balance scorecard (BSC) performance model which was developed by Kaplan \& Norton, (1996). Balance scorecard model provides an excellent system for performance measurement in the commercial banking industry Bremser and Chung(2005). The BSC is the major element of a strategic management system that enables organizations to translate strategic goals into measures of performance. The measures consist both financial and non-financial measures which serves as indicators used in monitoring strategy implementation throughout the organization and whether strategic goals are being achieved or not (Bremser \& Chung, 2005).The framework comprises of four (1 financial, and 3 non-financial aspects (customer perspective, internal process, learning \& growth).

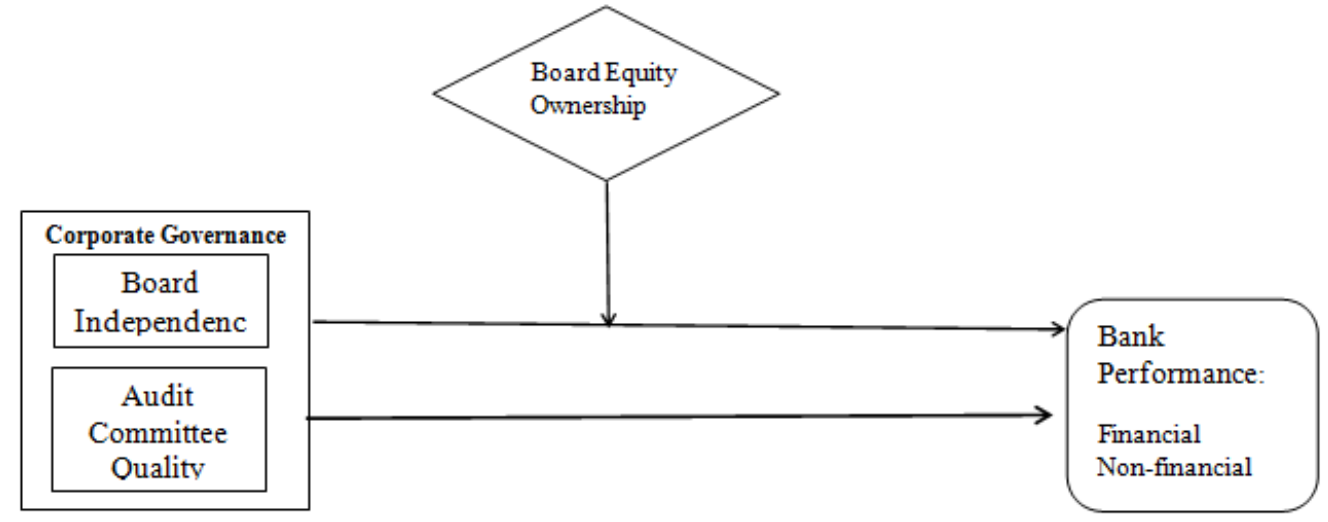

Figure 1 Proposed Framework

\section{Conclusion}

This paper is a proposes a framework based on an ongoing research, to examine the influence of equity shareholding in motivating Board of directors of banks and improving their functional effectiveness in monitoring the managements' overall strategic system of control which will results in a better banks performance after the reform. If this proposed framework is validated and the study completed, the finding will provide significant contribution to the literature, managers and regulators.

\section{References}

[1]. Abbott, L. J., Parker, S., \& Peters, G. F. (2004). Audit Committee Characteristics and Restatements, 23(1), 69-87.

[2]. Abernathy, J. L., Herrmann, D., Kang, T., \& Krishnan, G. V. (2013). Audit committee financial expertise and properties of analyst earnings forecasts. Advances in Accounting, 29(1), 1-11. doi:10.1016/j.adiac.2012.12.001

[3]. Aburime, T. U. (2008). Aburime, T. U. (2008). Determinants of Bank Profitability: Company-Level Evidence from Nigeria. SSRN Electronic Journal, 1-31. doi:10.2139/ssrn.1106825Determinants of Bank Profitability: Company-Level Evidence from Nigeria. SSRN Electronic Journal, 1-31. doi:10.2139/ssrn.1106825

[4]. Adekoya, A. A. (2011). Corporate Governance Reforms in Nigeria: Challenges and Suggested Solutions. Journal of Business Syestems, Governance and Ethics, 6(1). Retrieved from www.jbsge.vu.edu.au

[5]. Albring, S., Robinson, D., \& Robinson, M. (2013). Audit committee financial expertise, corporate governance, and the voluntary switch from auditor-provided to non-auditor-provided tax services. Advances in Accounting, Incorporating Advances in International Accounting, 1 -14. doi:10.1016/j.adiac.2013.12.007

[6]. Baron, R. M., \& Kenny, D. A. (1986). The moderator-mediator variable distinction in social psychological research: conceptual, strategic, and statistical considerations. Journal of Personality and Social Psychology, 51(6), 1173-82. Retrieved from http://www.ncbi.nlm.nih. gov/pubmed/3806354

[7]. Beck, T., Cull, R., \& Jerome, A. (2005). Bank privatization and performance: Empirical evidence from Nigeria. Journal of Banking \& Finance, 29(8-9), 2355-2379. doi:10.1016/j.jbankfin. 2005.03.018

[8]. Bhagat, S., \& Black, B. (2000). Board Independence and Long-Term Firm Performance, 2000 (February), 1-44. 
Moderating role of Boards' Equity ownership on the relationship between Corporate Governance ..

[9]. Bhagat, S., \& Bolton, B. (2008). Corporate governance and firm performance. Journal of Corporate Finance, 14(3), $257-273$. doi:10.1016/j.jcorpfin.2008.03.006

[10]. Bremser, W. G., \& Chung, Q. B. (2005). A framework for performance measurement in the e-business environment. Electronic Commerce Research and Applications, 4(4), 395-412. doi:10.1016/j.elerap.2005.07.001

[11]. Byun, H. S., Lee, J. H., \& Park, K. S. (2013). Ownership Structure, Intensive Board Monitoring, and Firm Value: Evidence from Korea. Asia-Pacific Journal of Financial Studies, 42(2), 191-227. doi:10.1111/ajfs.12012

[12]. Carol Liu, M. H., Tiras, S. L., \& Zhuang, Z. (2014). Audit committee accounting expertise, expectations management, and nonnegative earnings surprises. Journal of Accounting and Public Policy, 1. doi:10.1016/j.jaccpubpol.2013.12.004

[13]. CBN, (2008). Central Bank of Nigeria. Banking supervision annual report. Nigeria. Retrieved from www.cenbank.org

[14]. CBN, (2010). Central Bank of Nigeria Governor (pp. 0-11). Retrieved from www.cbnnigeria.org

[15]. De Villiers, C., Naiker, V., \& van Staden, C. J. (2011). The Effect of Board Characteristics on Firm Environmental Performance. Journal of Management, 37(6), 1636-1663. doi:10.1177/0149206 311411506

[16]. DeZoort, F. T., Hermanson, D. R., \& Houston, R. W. (2003). Audit committee support for auditors: The effects of materiality justification and accounting precision. Journal of Accounting and Public Policy, 22(2), 175-199. doi:10.1016/S02784254(03)00007-3

[17]. Fama, E. F., \& Jensen, M. C. (1983). The University of Chicago The Booth School of Business of the University of Chicago The University of Chicago Law School Separation of Ownership and Control SEPARATION OF OWNERSHIP AND CONTROL *. Journal of Law and Economics, 26(2), 301-325.

[18]. Guest, P. M. (2008). The determinants of board size and composition: Evidence from the UK. Journal of Corporate Finance, 14(1), 51-72. doi:10.1016/j.jcorpfin.2008.01.002

[19]. Hermalin, B., \& Weisbach, M. S. (1991). The effects of board composition and direct incentives on firm performance. Financial Management. Retrieved from http://www.jstor.org/stable/3665716

[20]. Hillman, A. J., \& Dalziel, T. (2003). Boards of Directors and Firm Performance: Integrating Agency and Resource Dependence Perspectives. The Academy of Management Review. Retrieved from http://www.jstor.org/stable/pdfplus/30040728.pdf?accept $\mathrm{TC}=$ true \&accept $\mathrm{TC}=$ true \&jpdConfirm $=$ true

[21]. Iganiga, B. O. (2010). Evaluation of the Nigerian Financial Sector Reforms Using Behavioral Models, 1(July 2004), 65-75.

[22]. Jensen, M. C., \& Meckling, W. H. (1976). Theory of the firm: Managerial behavior, agency costs and ownership structure. Journal of Financial Economics, 3(4), 305-360. doi:10.1016/0304-405X(76)90026-X

[23]. Kuye, O. L., Ogundele, O. J. K., \& Otike-Obaro, A. (2013). Government Bailout of Financially Distressed Banks in Nigeria: A Justifiable Strategy? O . L . Kuye Department of Business Administration University of Lagos Lagos State O . J . K . Ogundele Department of Business Administration University of Lagos Lago. International Journal of Business and Social Science, 4(8), 174180.

[24]. Lefort, F., \& Urzúa, F. (2008). Board independence, firm performance and ownership concentration: Evidence from Chile. Journal of Business Research, 61(6), 615-622. doi:10.1016/j.jbusres. 2007.06.036

[25]. NDIC, (2011). Resolution of Failing Banks Through The Establishment Of Bridge, (Aug, 2011).

[26]. Nworji, I. D. (2011). Corporate Governance and Bank Failure in Nigeria: Issues, Challenges and Opportunities, 2(2).

[27]. Oghojafor, B. E. A., Olayemi, O. O., Okonjia, P. S., \& Okolie, J. U. (2010). Poor Corporate Governance and its consequences on the Nigerian banking sector, 5(2), 243-250.

[28]. Okereke, E. J., Abu, S., \& Anyanwu, G. I. (2011). Impact of Corporate Governance on the Performance of Nigerian Deposit Money Banks. Indian Journal of Corporate Governance, 4(2), 15-27.

[29]. Onakoya, A. B. O., Ofoegbu, D. I., \& Fasanya, I. O. (2012). Corporate Governance and Bank Performance: A Pooled Study Of Selected Banks In Nigeria. European Scientific Journal, 8(28), 155-164.

[30]. Sanda, A., Mikailu, A. ., \& Garba, T. (2005). Corporate governance mechanisms and firm financial performance in Nigeria.

[31]. Sanusi, \& CBN. (2010). “ The Nigerian Banking Industry: what went wrong and the way forward " Governor , Central Bank of Nigeria (pp. 1-23). kano.

[32]. Sanusi, S. L. (2010). Global financial meltdown and the reforms in the nigerian banking sector (pp. 1-28).

[33]. Uwuigbe, O. R., \& Fakile, A. S. (2012). The Effects of Board Size on Financial Performance of Banks: A Study of Listed Banks in Nigeria. International Journal of Economics and Finance, 4(2), 260-267. doi:10.5539/ijef.v4n2p260

[34]. Zahra, S. ., \& Pearce, J. . (1989). Boards of Directors and Corporate Financial Performance : A Review and integrative Modei, 15(2), 291-334

[35]. Zhang, Y., Zhou, J., \& Zhou, N. (2007). Audit committee quality, auditor independence, and internal control weaknesses. Journal of Accounting and Public Policy, 26(3), 300-327. doi:10.1016/j.jaccpubpol.2007.03.001 